\title{
Transcriptional Activation by the E1A Regions of Adenovirus Types 40 and 41
}

\author{
A. E. van Loon, ${ }^{1}$ P. Gilardi, ${ }^{*}$ M. Perricaudet, ${ }^{*}$ Th. H. Rozijn, ${ }^{2}$ and J. S. Sussenbach \\ Laboratory for Physiological Chemistry, State University at Utrecht, Vondellaan 24A, 3521 GG Utrecht, The Netherlands, and *institut de \\ Recherches Scientifiques sur le Cancer, Centre National de la Recherche Scientifique, 94800 Villejuif, France
}

Received March 30, 1987; accepted May 29, 1987

\begin{abstract}
In order to establish whether the poor growth of the two fastidious adenoviruses types 40 and 41 (Ad40 and Ad41) in HeLa cells is due to a reduced trans-activation by the early region $1 \mathrm{~A}(\mathrm{E} 1 \mathrm{~A})$, we have determined the trans-activating effect of this region on the expression of the chloramphenicol acetyltransferase (CAT) gene controlled by the Ad2 E4 promoter. Cotransfection of HeLa cells with plasmids containing the E1A regions of Ad5, Ad40, and Ad41, respectively, and the CAT gene controlled by the Ad2 E4 promoter showed that activation of the E4 promoter by the E1A regions of Ad40 and Ad41 depends on the same sequence elements of the E4 promoter as activation by the Ad5 E1A gene products. The level of activation, however, is significantly lower. This might partly explain the reduced growth in HeLa cells of the two viruses. 1987 Academic Press, Inc.
\end{abstract}

The human adenoviruses 40 and 41 (Ad40 and Ad41) grow very poorly in cell lines normally used for the propagation of adenoviruses (e.g., HeLa cells) (1). However, these fastidious viruses grow to some extent $(2,3)$ in the Ad5-transformed human embryonic kidney (HEK) cell line 293 (4), which contains and expresses the Ad5 early region $E 1$. This suggests that the multiplication block of Ad40 and Ad41 in HeLa cells, probably situated early in the productive cycle (5), is due to a disability of the $\mathrm{Ad} 40$ and $\mathrm{Ad} 41 \mathrm{E} 1$ regions or their gene products to function properly in HeLa cells.

The $E 1$ region of human adenoviruses consists of two transcriptional units, the subregions $\mathrm{E} 1 \mathrm{~A}$ and $\mathrm{E} 1 \mathrm{~B}$ (6). Both these regions are involved in cell transformation (7). Previously, we showed that the left terminal 12 and $11 \%$ of the Ad40 and Ad41 genomes, respectively, are able to transform rodent cells in vitro (8). Thus, in this respect the $E 1$ regions of these viruses are essentially similar to those of other human adenoviruses. Region E1A gene products have also been shown to stimulate the transcription of the other early viral regions $\mathrm{E} 1 \mathrm{~B}, \mathrm{E2}, \mathrm{E} 3$, and $\mathrm{E} 4$. This $\mathrm{E} 1$-mediated trans-activation is an essential function in the productive cycle of adenoviruses $(9-13)$.

The E1A gene products probably do not interact directly with the promoter/enhancer sequences of the trans-activated genes, but raise the concentration of transcription factors $(14,15)$ or decrease the level of inhibitory factors (16). In the case of the E4 promoter the transcription is strongly dependent on the E1A gene

\footnotetext{
'Current address: Department of Experimental Zoology, State University of Utrecht, Padualaan 8, 3505 TB Utrecht, The Netherlands.

${ }^{2}$ To whom requests for reprints should be addressed.
}

product, which results in a low level of transcription when the E1A gene is not present (17). The E4 promoter region is located at the right terminus of the Ad2 genome with the cap site at $329 \mathrm{bp}$ from the end of the Ad2 DNA. The trans-activation of the E4 promoter by the Ad2 and Ad5 E1A gene product is dependent on two sequence elements between positions -179 to -158 and positions -239 to -218 relative to the start of the transcription of the E4 gene (18). Deletion of one such element does not affect the E1A transactivation of the $E 4$ promoter. Deletion of both upstream sequences, however, strongly reduces the E1A trans-activation. Both these regulatory elements contain an octanucleotide sequence that is also present in the upstream elements critical for the E1A transactivation of the E2 and E3 promoters (18).

The poor growth of the fastidious adenoviruses in HeLa cells could be due to a relative inability of their E1A genes to trans-activate other early viral genes. We therefore decided to study the trans-activation of the Ad2 E4 promoter by the Ad40 and Ad41 E1A genes in both the human HeLa cells, in which Ad40 and Ad41 replicate poorly, and in baby rat kidney (BRK) cells, which can be transformed relatively easily by the $A d 40$ and $A d 41$ E1 regions. For that purpose we used the following plasmids: pE4CAT, in which the chloramphenicol acetyltransferase (CAT) gene is placed under control of the whole E4 promoter region; pE4CAT $(-179)$ which lacks the sequence upstream from position -179 , including one of the regulatory elements; and pE4CAT $(-89)$ in which the sequences upstream from position -89 are deleted, including both regulatory elements $(17,18)$. The extent of trans-activation of the $E 4$ promoter by the adenovirus $E 1 A$ gene 
products can be determined by measuring the transient expression of CAT activity after transfection of these plasmids into either HeLa cells cotransfected with plasmids carrying the $\mathrm{E} 1 \mathrm{~A}$ region of $\mathrm{Ad5}, \mathrm{Ad} 40$, or Ad41, or BRK cells that are transformed by the Ad40 and $A d 41 E 1$ region. The last assay system is comparable to the Ad5-transformed HEK cells (293 cells) used by others (17).

In a control experiment untransformed BRK cells and HEK cells, and HeLa cells not cotransfected with the E1A plasmids, were transfected with pE4CAT $(-179)$, and $p E 4 C A T(-89)$, respectively. Cells were grown as described before (8). Transfection was performed essentially as described (19-21). Cells were plated at 2.5 $\times 10^{6} \mathrm{cells} / \mathrm{cm}^{2}$ in $10-\mathrm{cm}$ dishes and the medium was refreshed after $24 \mathrm{hr}$. Four hours later the cells were transfected with the plasmid using the calcium phosphate coprecipitation procedure (21). A 3-min glycerol shock $(15 \%$ in HEPES-buffered saline $(19,20)$ ) was given $3.5 \mathrm{hr}$ after the precipitate was brought onto the cells. After $40 \mathrm{hr}$ the transfected cells were harvested and CAT assays were performed as described (22). As shown in Fig. 1 the E4 promoter is activated in BRK cells as is pE4CAT $(-179)$ which contains only one of the elements required for the activation by the $\mathrm{Ad} 2 / 5$ E1A region. In contrast, pE4CAT(-89), which lacks both these elements, is activated very weakly in the primary BRK cells. In HEK or HeLa cells the E4 promoter is not activated, as was reported before for HeLa cells (17). The finding that the E4 promoter is activated in primary BRK cells in a way that is dependent on the same regulatory elements as is the E1A trans-activation indicates that in contrast to HeLa cells BRK cells are

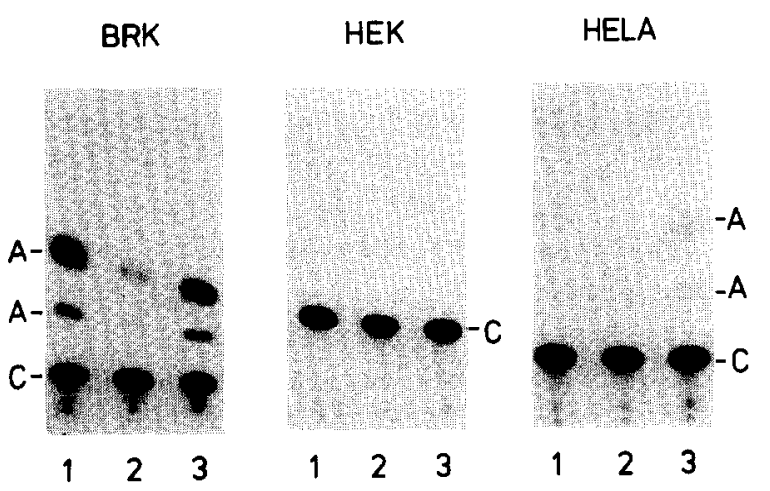

FIG. 1. Activity of the Ad2 E4 promoter in primary BRK, HEK, and HeLa cells. CAT assays were used to measure the promoter activity. A $150-\mu$ lysate was made from cells of one $10-\mathrm{cm}$ dish (see text). Half of the lysate was incubated in $150 \mu$ lassay buffer $(250 \mathrm{mM}$ Tris, $\mathrm{pH} 7.4)$ with $4 \mathrm{mM}$ acetyl-CoA and $0.25 \mu \mathrm{Ci}$ of $\left[{ }^{14} \mathrm{C}\right]$ chloramphenicol $(50 \mathrm{nCi} / \mathrm{mM})$ for $1.5 \mathrm{hr}$. Acetylated $(A)$ and nonacetylated $(C)$ chloramphenicol were separated by ascending thin-layer chromatography (22). The plasmids pE4CAT (lanes 1), pE4CAT(-89) (lanes 2), and pE4CAT(-179) (lanes 3 ) were used in the transfection (see text).

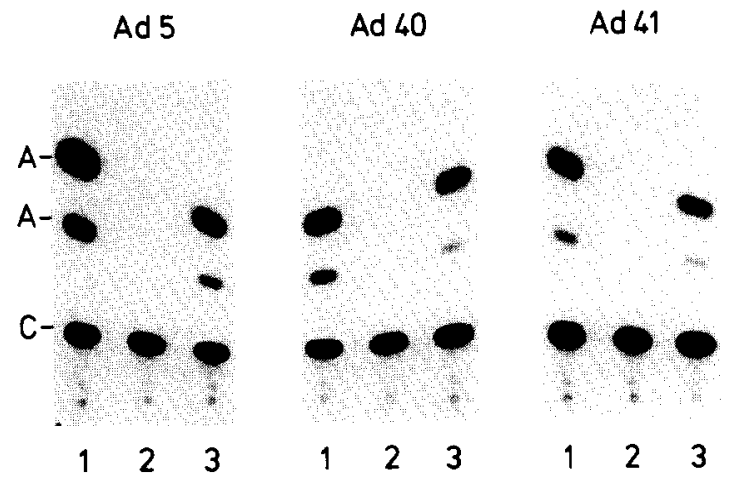

Fig. 2. Activity of the Ad2 E4 promoter in HeLa cells transfected with the E1A regions of $A d 5, A d 40$, and Ad41, respectively. CAT assays were used to measure the promoter activity. Transfections and CAT assays were performed as described in the text and Fig. 1. The plasmids pE4CAT (lanes 1), pE4CAT(-89) (lanes 2), and pE4CAT(-179) (lanes 3) were used in the transfection (see text). Acetylated $(A)$ and nonacetylated $(C)$ chloramphenicol are indicated.

in a permissive state for these regulatory elements. This finding supports the assumption that the upstream elements are regulated by cellular factors that modulate the enhancer activity (18). The BRK cells resemble F9 embryonal carcinoma cells in the aforementioned respect. Undifferentiated but not differentiated F9 cells allow adenovirus early gene expression in the absence of the $E 1 A$ region $(23,24)$.

The permissive state of primary BRK cells renders Ad40 and Ad41 transformed BRK cells unfit for use in an assay of the E1A-mediated trans-activation of the E4 promoter. The transcriptional activation by the E1A regions of $A d 5, A d 40$, and $A d 41$ was therefore assayed only in HeLa cells which were cotransfected with the E4CAT plasmids and E1A plasmids carrying the left terminal Ad5 Pstl fragment (5.0\%), the left terminal Ad40 Bc/l fragment (4.8\%) (25), or the left terminal Ad41 Sacll fragment (4.0\%) (van Loon et al., manuscript in preparation). Ten micrograms of the E1A plasmid together with $10 \mu \mathrm{g}$ of pE4CAT, pE4CAT(-179), or pE4CAT(-89) were used to transfect the cells and CAT assays were performed. The results are presented in Fig. 2. Both pE4CAT and pE4CAT(-179) are activated by the $\mathrm{E} 1 \mathrm{~A}$ regions of $\mathrm{Ad} 5, \mathrm{Ad} 40$, and $\mathrm{Ad} 41$. However, no activation of $p E 4 C A T(-89)$ could be detected. This shows that the trans-activation by the E1A genes of $\mathrm{Ad} 40$ and $\mathrm{Ad} 41$ depends on the presence of upstream sequences in a region that is also required for the transactivation by the Ad5 E1A gene product.

The trans-activation of the different $E 1 A$ regions was quantitated by measuring the ${ }^{14} \mathrm{C}$ radioactivity present in the acetylated and nonacetylated forms of chloramphenicol and calculating the percentage of the original input of the chloramphenicol which was converted into the acetylated form. Three different experiments 
with three different isolates of the plasmids were compared. The relative amount of acetylated chloramphenicol produced by extracts from cells transfected with the Ad5 E1A region and pE4CAT was $37 \pm 5 \%$. Trans-activation of pE4CAT by the Ad40 and Ad41 E1A resulted in $8 \pm 6$ and $8 \pm 2 \%$ acetylated chloramphenicol, respectively. The background level was less than $1 \%$. The low level of trans-activation could be due to a poor expression of the Ad40 and Ad41 E1A genes in HeLa cells, or to a relative inability of the Ad40 and Ad41 E1A polypeptides to regulate either the Ad2 E4 promoter or the cellular factors that presumably mediate the trans-activation by the E1A gene product. Although more work is needed to completely understand the relation between the functioning of the $\mathrm{Ad} 40$ and Ad41 E1A genes in Hela cells and the fastidious growth, our observation supports the notion that a malfunctioning of the Ad40 and Ad41 E1A genes or their products in HeLa cells is at least one of the factors responsible for the fastidious growth characteristics.

\section{ACKNOWLEDGMENTS}

The excellent technical assistance of A.M.C.B. Reemst is gratefully acknowledged. These investigations were supported in part by the Foundation for Medical Research FUNGO, which is subsidized by the Netherlands Organization for the Advancement of Pure Rescarch (ZWO).

\section{REFERENCES}

1. DE JONG, J. C., WigAND, R., KidD, A. H., WADELL, G., Kapsenberg, J. G., Muzerie, C. J., Wermenbol, A. G., and Firtzlaff, R. G., J. Med. Virol. 11, 215-231 (1983).

2. Kidd, A. K., and Madeley, C. R., J. Clin. Pathol. 34, 213-216 (1981).

3. TakifF, H. E., Straus, S. E., and Garon, C. F., Lancet 2, 832834 (1981).
4. Graham, F. L., Smiley, J., Russel, W. C., and NaiRn, R., J. Gen. Virol. 36, 59-72 (1977).

5. Takiff, H. E., and Straus, S. E., J. Med. Virol. 9, 93-100 (1982).

6. Sussenbach, J. S., In "The Adenoviruses" (H. S. Ginsberg, Ed.), pp. 35-124. Plenum, New York/London, 1984.

7. Graham, F. L., In "The Adenoviruses" (H. S. Ginsberg, Ed.), pp. 339-398. Plenum, New York/London, 1984.

8. van Loon, A. E., MaAs, R., Vaessen, R. T. M. J., Reemst, A. M. C. B., Sussenbach, J. S., and Rozin, TH. H., Virology $147,227-230$ (1985).

9. JONES, N., and SHENk, T., Proc. Natl. Acad. Sci. USA 76, 36653669 (1979).

10. NeVInS, J. R., Cell 26, 213-220 (1981).

11. Berk, A. J., Lee, F., Harrison, T., Williams, J., and Sharp, S. A., Cell 17, 935-944 (1979).

12. Sharp, P. A., In "The Adenoviruses" (H. S. Ginsberg, Ed.), pp. 172-204. Plenum, New York/London, 1984.

13. BOS, J. L., and TEN WOLDE-KRAAMWINKEL, H. C., EMBO J. 2, 7376 (1983).

14. Hoeffler, W. K., and Roeder, R. G., Cell 41, 955-963 (1985).

15. Yoshinaga, S., Dean, N., Han, M., and Berk, A. J., EMBO J. 5, 343-354 (1986)

16. Jalinot, P., and Kedinger, C., Nucleic Acids Res. 14, 2651-2669 (1986).

17. Gillardi, P., and Perricaudet, M., Nucleic Acids Res. 12, $7877-$ $7888(1984)$.

18. Gilardi, P., and Perricaudet, M., Nucleic Acids Res. 14, 903b9049 (1986).

19. Frost, E., and Williams, J., Virology $91,39-50$ (1978).

20. PARKer, B. A., and Stark, G. R., J. Virol. 31, 360-369 (1979).

21. van Der EB, A. J., and Graham, F. L., In "Methods in Enzymology" (L. Grossman and K. Moldave, Eds.), Vol. 65, pp. 826-839. Academic Press, New York, 1980.

22. Gorman, C. M., Moffat, L. F., and Howard, B. H., Mol. Cell. Biol. 2, 1044-1051 (1982).

23. Hen, R., Borrelli, E., Fromental, C., Sassone-Corsi, P., and ChAMBOn, P., Nature (London) 321, 249-251 (1986).

24. Imperiale, M. J., KaO, H.-T., Feldman, L. T., Nevins, J. R., and StRICKLAND, S., Mol. Cell. Biol. 4, 867-874 (1984).

25. van LOON, A. E., ROzIJN, TH. H., DE JONG, J. C., and SussenbaCh, J. S., Virology 140, 197-200 (1985) 